\title{
COMPARATIVE STUDY BETWEEN CONVENTIONAL INFERIOR TURBINECTOMY AND ENDOSCOPIC INFERIOR TURBINOPLASTY FOR TREATMENT OF INFERIOR TURBINATE HYPERTROPHY
}

\author{
Atif Rafique, Maqbool Raza, Shahid Farooq Khattak, Muhammad Ali*, Khalid Azam**, Muhammad Zubair*** \\ Combined Military Hospital Multan/National University of Medical Sciences (NUMS) Pakistan, ${ }^{*}$ Combined Military Hospital /National University of Medical \\ Sciences (NUMS) Rawalpindi Pakistan, ${ }^{* *}$ Combined Military Hospital Lahore/National University of Medical Sciences (NUMS) Pakistan, ${ }^{* * *}$ Combined Military \\ Hospital Kohat/National University of Medical Sciences (NUMS) Pakistan
}

\section{ABSTRACT}

Objective: To compare efficacy of endoscopic turbinoplasty versus conventional inferior turbinectomy for hypertrophy of inferior turbinate.

Study Design: Comparative prospective study.

Place and Duration of Study: Ear, Nose and Throat (ENT) Department Combined Military Hospital (CMH) Multan, from Jun 2019 to May 2020.

Methodology: This study comprised of 50 patients of various age groups and both genders. Patients were grouped into two groups A and B, each group having 25 patients through random sampling. Patients in group A had endoscopic turbinoplasty whereas patients in group B had partial turbinectomy through conventional surgical method. Patients were followed regularly in both groups and were inspected postoperatively at 2 weeks, after 1 month and after 3 months.

Results: Patients who underwent Endoscopic turbinoplasty experienced less pain $(p<0.05)$ postoperatively at 2 weeks compared to conventional surgical turbinectomy. In addition, these patients showed statistically significant healing and reduced crusting at 1 month postoperatively. At 3 months post operatively all patients had healed completely as opposed to only $72 \%$ with surgical turbinectomy.

Conclusion: Endoscopic turbinoplasty is more effective than conventional surgical technique for inferior turbinate hypertrophy as it leads to less post-operative pain, reduced nasal crusting and earlier healing.

Keywords: Conventional turbinectomy, Endoscopic turbinoplasty, Inferior turbinate, Nasal obstruction.

How to Cite This Article: Rafique A, Raza M, Khattak SF, Ali M, Azam K, Zubair M. Comparative Study Between Conventional Inferior Turbinectomy and Endoscopic Inferior Turbinoplasty for Treatment of Inferior Turbinate Hypertrophy. Pak Armed Forces Med J 2021; 71 (Suppl-3): S617-621. Doi: https://doi.org/10.51253/pafmj.v1i1.4738

This is an Open Access article distributed under the terms of the Creative Commons Attribution License (https://creativecommons.org/licenses/by-nc/4.0/), which permits unrestricted use, distribution, and reproduction in any medium, provided the original work is properly cited.

\section{INTRODUCTION}

Inferior turbinate hypertrophy causing chronic nasal obstruction is a common problem being faced by Rhinologist. Various diseases like vasomotor rhinitis, Allergic rhinitis and excessive use of topical vasoconstrictors can lead to inferior turbinate enlargement. ${ }^{1}$

Swelling of the sub-mucosa is the primary reason of the enlarged turbinates whereas bone retains the normal size. In intrinsic rhinitis, enlargement of inferior turbinate is caused by sub-mucosal venous sinusoids getting dilated, and reacts to decongestant. At times, the inferior turbinate enlargement due to submucosal fibrosis does not react to decongestant, antihistamines, intranasal corticosteroid sprays, corticosteroid injections and surgery (turbinate reduction) is indicated. ${ }^{2}$ The aetiology of turbinate malfunction is based on many factors. Turbinate's have a very abundant supply of blood from both internal and external carotid artery systems, and receive nerve supply

Correspondence: Dr Maqbool Raza, Associate Professor of ENT, Combined Military Hospital Multan Pakistan from both sympathetic and parasympathetic nervous systems, anything that disturbs either of these two systems can affect the size of the turbinate's and, henceforth, the nose itself. ${ }^{3}$ Turbinate reduction was found to not only improve nasal patency but was also associated with reduced attacks of headache in a study by Hammad et al. ${ }^{4}$ Diverse surgical procedures have been used to treat inferior turbinate hypertrophy e.g., electriccautery, silver nitrate cautery, sub mucosal diathermy, laser, inferior turbinectomy and now the newer endoscopic inferior turbinoplasty.

A variety of complications like crust development, synechiae formation, feeling of dryness and atrophic rhinitis have been reported after turbinate procedures. $^{5}$

The aim of surgery is to decrease the inferior turbinate size so that the symptoms get reduced while conserving the anatomy and function of the nasal air ways. ${ }^{6}$ The study was done to compare endoscopic turbinoplasty and limited surgical inferior turbinate reduction in chronic hypertrophied turbinates regard- 
less of reason for relieving the nasal blockade, amount of crusting in nose, post-operative nasal pain and the healing of tissues and synechiae formation.

\section{METHODOLOGY}

This was a comparative prospective study that was carried at ENT department, Combined Military Hospital Multan Pakistan, from June 2019 to May 2020, to see how effective Endoscopic inferior turbinoplasty is against partial surgical inferior turbinectomy in patients suffering from chronic hypertrophic rhinitis producing nasal blockade. The study comprised of 50 patients of different age groups and both gender. Patients were distributed in two separate groups (A and B), both group having 25 patients each. Patients were assigned these two groups using simple random tables. Patients in group (A) had endoscopic turbinoplasty while the patients in group (B) underwent partial inferior turbinate reduction through conventional surgical resection of inferior turbinate. Informed written consent was obtained from all the patients were enrolling them into this study.

In this study, we included patients with nasal blockade of both sides or stuffiness caused by bilateral inferior turbinate hypertrophy refractory to medications, and none of patients had previous nasal surgery while all the patients had normal nasopharynx when examined. Exclusion criterions in our study were: Patients with other conditions leading to nasal blockade such as; gross deviated nasal septum, concha bullosa and nasal polyposis.

Detailed history was taken from all the enrolled patients with particular attention to symptoms produced by nasal diseases (Itching and sneezing, nasal blockade, discharge from nose, and snoring). Nasal endoscope $0^{\circ},(2.7 \mathrm{~mm}$ and $4 \mathrm{~mm}$ diameter) was used, to assess the condition of nasal turbinated without the topical decongestant spray both before and after the surgery according to the grading system defined. Each

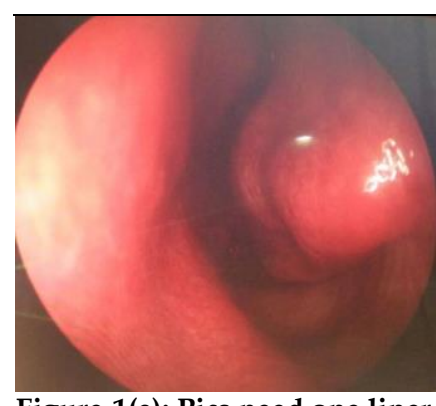

Figure-1(a): Pics need one liner illustration, Endoscopic view of enlaged turbinate.

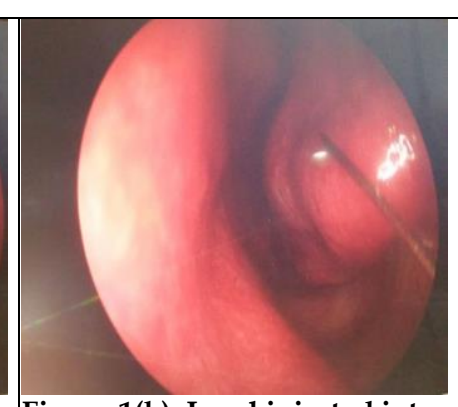

Figure-1(b): Local injected into turbinate using dental syringe. patient underwent a Computed Tomography (CT) scan of paranasal sinuses in all the three planes (coronal, axial and sagittal views). Endoscopic turbinoplasty was done in all patients in group A, whereas patients in group $\mathrm{B}$ had turbinate reduction through conventional surgical technique.

For Partial inferior turbinectomy by conventional method (PIT), the inferior turbinate was infiltrated with adrenaline, xylocaine (1:1000) along the whole length of turbinate. The inferior turbinate were fractured using blunt freer elevator, and then clamp forceps were applied to crush the mucosa so that it did not bleed after cutting. Turbinectomy scissors were used to cut the anterior and mid portion of the inferior turbinate taking care to cut medial to crushed portion.

Endoscopic resection of hypertrophied inferior turbinate (turbinoplasty) was done with the help of microdebrider.Nasal cavity was packed with ribbon gauze soaked in adrenaline 1:1000 with $2 \%$ xylocaine for 10 minutes and inferior turbinate was infiltrated with same. Verticle incision made on head of turbinate, microdebrider was introduced inside the cavernous tissue of inf turbinate and moved forward till the posterior end of the turbinate. Bleeding if any secured. Nasal packing was optional depending upon the experties of the surgeon.

\section{Postoperative Follow Up}

Patients were followed up at 15 days, one month and three months post operatively and were compared for below mentioned parameters: A. Relief in nasal blockade. B. Severity of nasal pain. C. Extent of nasal crusting. D. Tissue healing extent and synechiae formation.

Nasal blockade was analysed using VAS (Visual Analogue Score) system by asking the patients to score reprieve of nasal obstruction post-operatively from 1-10 and was categorized as: No improvement: VAS (1-3), Partial improvement: VAS (4-7), and Complete
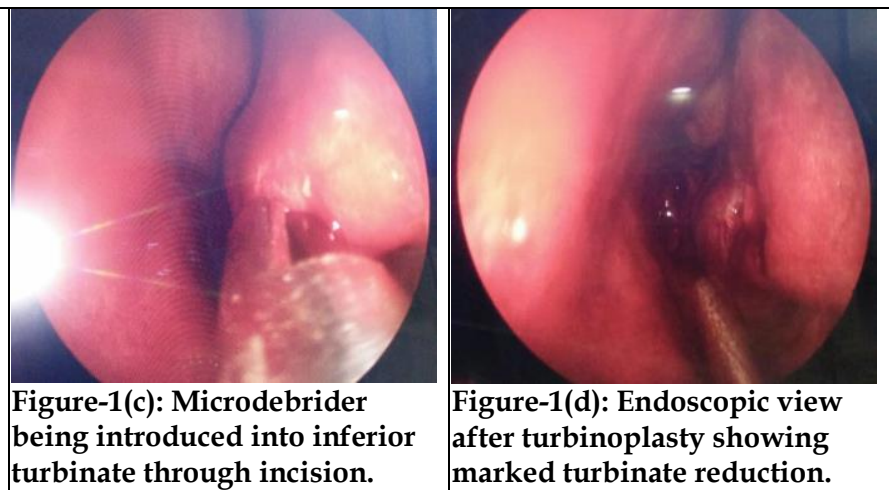

Figure-1(d): Endoscopic view after turbinoplasty showing marked turbinate reduction. 
improvement: VAS (8-10).

Intranasal pain was also analysed according to VAS by asking the patients to score the post-operative pain from 1-10 and was categorized as: mild pain: 1-3, moderate pain: 4-7, and severe pain: 8-10.

Extend of intra-nasal crusting was analysed according to endoscopic scoring of Lund and Kennedy as: Grade 0: Absence of crusting. Grade 1: Mild crusting: partially filling the nasal cavity. Grade 2: Severe crusting: fully filling the nasal cavity.

Tissue healing was assessed also according to endoscopic scoring of Lund and Kennedy: It was taken as good healing if there was rapid mucosal re-epithelisation, minimal crusting, no nasal synechiae, patient feel relief of nasal symptoms. It was taken as Moderate healing: Mucosal re-epithelisation, mild to moderate crusting, with nasal synechiae, patient feel relief of nasal symptoms. Poor healing: Delayed mucosal reepithelisation, severe crusting and nasal synechiae, persistent inflammations and infection and patient doesn't feel relief of his/her nasal symptoms. In both groups Follow up was carried-out at following interval, two weeks, one month and three Months postoperatively to assess the previous parameters.

SPSS-20 (programme for statistical analysis) was used for data entry and analysis. Microsoft office 2010 was used for graphs. Quantitative data were presented by mean and standard deviation, while qualitative data were presented by frequency distribution. Chi square test was used to compare between two or more proportions.

\section{RESULTS}

The study was done on fifty patients, 27 (54\%) were females and $23(46 \%)$ were males. Patients were in the age range of 15-62 years with mean age $28.30 \pm$ 7.5 years (figure-2).

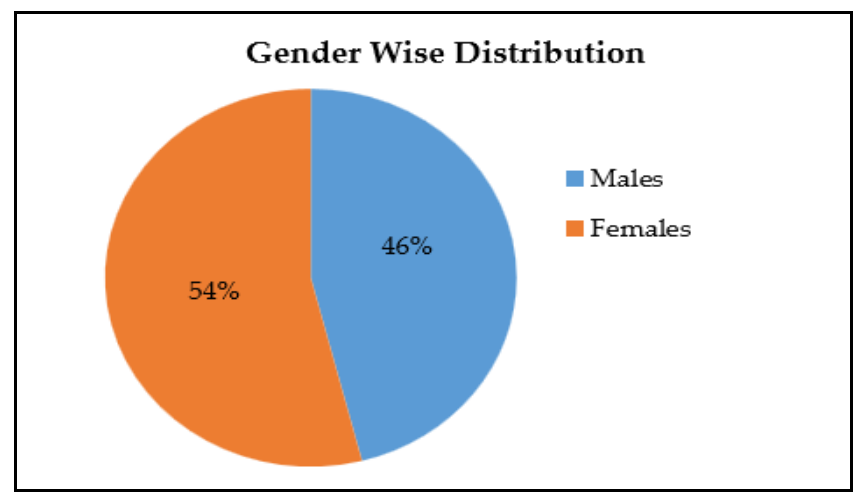

Figure-2: Gender wide distribution of patients.
At 2 weeks post-operative inspection relief of nasal obstruction was very comparable in both the groups and difference in crusting was statistically insignificant. However, there was statistically significant difference in pain in both groups as shown by $p$-value less than 0.05 on chi square test. Table-I shows comparison of both groups at 2 weeks post operatively.

Table-I: Comparison between both groups at 2 weeks of postoperatively $(n=25)$.

\begin{tabular}{|c|c|c|c|}
\hline & \multirow{2}{*}{$\begin{array}{c}\begin{array}{c}\text { Endoscopic } \\
\text { Turbinoplasty }\end{array} \\
\mathbf{n}(\%)\end{array}$} & \multicolumn{2}{|c|}{$\begin{array}{l}\text { Partial Inferior } \\
\text { Turbinectomy }\end{array}$} \\
\hline & & n (\%) & $p$-value \\
\hline \multicolumn{4}{|l|}{ Nasal Obstruction } \\
\hline No Improvement & - & - & \multirow{3}{*}{0.684} \\
\hline Partial Improvement & $3(12 \%)$ & $4(16 \%)$ & \\
\hline $\begin{array}{l}\text { Complete } \\
\text { Improvement }\end{array}$ & $22(88 \%)$ & $21(84 \%)$ & \\
\hline \multicolumn{4}{|l|}{ Pain } \\
\hline Mild & $23(92 \%)$ & $15(60 \%)$ & \multirow{3}{*}{0.047} \\
\hline Moderate & $2(8 \%)$ & $7(28 \%)$ & \\
\hline Severe & - & $3(12 \%)$ & \\
\hline \multicolumn{4}{|l|}{ Crustation } \\
\hline Absent crustations & $8(32 \%)$ & - & \multirow{3}{*}{0.754} \\
\hline Mild Crustations & $16(64 \%)$ & $18(72 \%)$ & \\
\hline Moderate crustations & $1(4 \%)$ & $7(28 \%)$ & \\
\hline
\end{tabular}

Patients in both groups were examined at 1 month post operatively. There was statistically significant difference in crusting and healing in both groups as evident by $p$-value 0.05 . However, relief of nasal obstruction was statistically insignificant between both techniques at one month post operatively. Table-II shows the comparison of both groups at 1 month.

Table-II: Comparison between both groups at 1 month postoperatively.

\begin{tabular}{|c|c|c|c|}
\hline & $\begin{array}{c}\text { Endoscopic } \\
\text { Turbinoplasty }\end{array}$ & $\begin{array}{c}\text { Partial inferior } \\
\text { turbinectomy }\end{array}$ & $\begin{array}{c}p- \\
\text { value }\end{array}$ \\
\hline \multicolumn{4}{|l|}{ Crustations } \\
\hline $\begin{array}{l}\text { Absence of } \\
\text { crustations }\end{array}$ & $22(88 \%)$ & $12(48 \%)$ & \multirow{3}{*}{0.008} \\
\hline Mild crustations & $3(12 \%)$ & $10(40 \%)$ & \\
\hline $\begin{array}{l}\text { Moderate } \\
\text { crustations }\end{array}$ & - & $3(12 \%)$ & \\
\hline \multicolumn{4}{|l|}{ Obstruction } \\
\hline No improvement & - & - & \multirow{3}{*}{0.637} \\
\hline $\begin{array}{l}\text { Partial } \\
\text { improvement }\end{array}$ & $2(8 \%)$ & $3(12 \%)$ & \\
\hline $\begin{array}{l}\text { Complete } \\
\text { improvement }\end{array}$ & $23(92 \%)$ & $22(88 \%)$ & \\
\hline \multicolumn{4}{|l|}{ Healing } \\
\hline Good & $22(88 \%)$ & $12(48 \%)$ & \multirow{3}{*}{0.002} \\
\hline Moderate & $3(12 \%)$ & $13(52 \%)$ & \\
\hline Poor & - & - & \\
\hline
\end{tabular}

Patients in both groups were again examined at 3 months and analysed as regards to nasal blockade, 
crusting and healing as per parameters explained previously. Healing in patients operated through endoscopic turbinoplasty was better and all patients achieved complete healing as compared to $76 \%$ patients in group B, signifying better healing in group A. Table-III shows comparison of both groups at 3 months post operatively.

Table-III: Comparison between both groups at 3 months postoperatively $(n=25)$.

\begin{tabular}{|c|c|c|c|}
\hline & $\begin{array}{l}\text { Endoscopic } \\
\text { turbinoplasty }\end{array}$ & $\begin{array}{l}\text { Partial inferior } \\
\text { turbinectomy }\end{array}$ & \multirow{2}{*}{$\begin{array}{c}p- \\
\text { value }\end{array}$} \\
\hline & n (\%) & n (\%) & \\
\hline \multicolumn{4}{|l|}{ Nasal Obstruction } \\
\hline No improvement & - & - & \multirow{3}{*}{0.637} \\
\hline $\begin{array}{l}\text { Partial } \\
\text { improvement }\end{array}$ & $2(4 \%)$ & $3(12 \%)$ & \\
\hline $\begin{array}{l}\text { Complete } \\
\text { improvement }\end{array}$ & $23(92 \%)$ & $22(88 \%)$ & \\
\hline \multicolumn{4}{|l|}{ Crustations } \\
\hline $\begin{array}{l}\text { Absent } \\
\text { Crustations }\end{array}$ & $25(100 \%)$ & $23(92 \%)$ & \multirow{3}{*}{0.149} \\
\hline Mild crustations & - & $2(8 \%)$ & \\
\hline Severe crustations & - & - & \\
\hline \multicolumn{4}{|l|}{ Healing } \\
\hline Good & $25(100 \%)$ & $19(76 \%)$ & \multirow{3}{*}{0.009} \\
\hline Moderate & - & $6(24 \%)$ & \\
\hline Poor & - & - & \\
\hline
\end{tabular}

\section{DISCUSSION}

Nasal blockade is the most frequent symptom encountered in rhinology outpatient department. ${ }^{1}$ Nasal obstruction can be caused by diverse range of nasal pathologies such as deviated nasal septum (DNS) or enlarged nasal turbinate's. Surgical reduction of the turbinate can be performed by utilizing variety of techniques. The procedures practised include total turbinectomy, turbinoplasty, partial inferior turbinectomy, sub mucosal resection, cryosurgery, laser assisted turbinoplasty, and electrocautery with monopolar or bipolar techniques.-14 Partial inferior turbinectomy is performed with an aim to remove nasal obstruction trying to preserve some portion of turbinate to maintain physiological function of turbinates. ${ }^{15,16}$

In our study, we compared conventional inferior turbinectomy and endoscopic inferior turbinoplasty. Our study results revealed that patients operated by both techniques had complained of persistent nasal obstruction at 2 weeks postoperatively with no statistically significant difference between the 2 groups and difference in reliving nasal blockade remained non-significant even at 3 months. Tables-IV \& V make comparison with the other published studies with our study as regards to the degree of nasal obstruction.
Table-IV: Enhancement of nasal airflow in after turbinoplasty in various studies in comparison to our study.

\begin{tabular}{|c|c|c|c|c|}
\hline Study & Year & Method & Nationality & Results \\
\hline Luczaj et al ${ }^{18}$ & 2007 & \multirow{3}{*}{$\begin{array}{c}\text { (by } \\
\text { Acoustic } \\
\text { Rhino- } \\
\text { metry) }\end{array}$} & Poland & $98 \%$ \\
\hline Fradis et al ${ }^{19}$ & 2000 & & USA & $76 \%$ \\
\hline $\begin{array}{l}\text { Warwick - } \\
\text { Brown }^{20}\end{array}$ & 1987 & & UK & $60 \%$ \\
\hline $\begin{array}{l}\text { Mohammad A } \\
\text { Gomma et al } 21\end{array}$ & 2014 & By VAS & Egypt & $88 \%$ \\
\hline $\begin{array}{l}\text { MP Kavin } \\
\text { Kumar }{ }^{22}\end{array}$ & 2018 & SNOT 22 & India & $100 \%$ \\
\hline Balegh H Ali ${ }^{23}$ & 2019 & by VAS & Egypt & $86 \%$ \\
\hline Our Study & 2020 & by VAS & Pakistan & $92 \%$ \\
\hline
\end{tabular}

Table-V: Enhancement of nasal airflow in patients with partial inferior turbinectomy in diverse studies in comparison to our study.

\begin{tabular}{|c|c|c|c|c|}
\hline Study & Year & Method & Nationality & Results \\
\hline Barbosa Ade et al & 2005 & \multirow{5}{*}{$\begin{array}{c}\text { (by } \\
\text { Acoustic } \\
\text { Rhino- } \\
\text { metry). }\end{array}$} & Brazil & $98 \%$ \\
\hline Fradis et al 19 & 2000 & & USA & $96 \%$ \\
\hline Rakover \& Rosen ${ }^{24}$ & 1996 & & USA & $77 \%$ \\
\hline Serrano $^{25}$ & 1996 & & France & $81.70 \%$ \\
\hline Pollock \& Rohrich & 1984 & & USA & $90 \%$ \\
\hline $\begin{array}{l}\text { Mohammad A. } \\
\text { Gomma et al } 21\end{array}$ & 2014 & By VAS & Egyl & $88^{\circ}$ \\
\hline M.P Kavin Kumar² & 2018 & SNOT 22 & India & $94 \%$ \\
\hline Balegh H Ali ${ }^{23}$ & 2019 & By VAS & Egypt & $84 \%$ \\
\hline Our Study & 2020 & By VAS & Pakistan & $88 \%$ \\
\hline
\end{tabular}

Salzano et al, in their study observed that $20 \%$ of patients who had sub mucus diathermy (SMD) complained of moderate pain whereas $80 \%$ patients reported experiencing mild pain at the end of 2 weeks postoperatively. ${ }^{3}$ In our study, $92 \%$ patients experienced only mild pain after turbinoplasty and further $8 \%$ of our patients had moderate pain. Also moderate crusting was found in only $4 \%$ of turbinoplasty patients on the $2^{\text {nd }}$ week post-operatively. In other studies by Imad and Salzano, moderate degree of intranasal crustations was observed in $44 \%$ of patients who had undergone SMD. In a study by Imad et al, 17 92\% of patients who had SMD of their turbinate were found to have good nasal tissue healing as opposed to patients with partial surgical inferior turbinectomy where only 52\% achieved satisfactory healing at the end of first postoperative month. Our study showed that turbinoplasty is better than partial surgical inferior turbinectomy regarding nasal pain at two weeks after surgery, but both techniques are found equally effective regarding the relieving of nasal obstruction and attaining good healing. Although our study has a small sample of patients, and follow-up duration was only 3 months however this study might inspire others to conduct more detailed studies with more objective assessment parameters of nasal air flow and longer duration of follow up. 


\section{Endoscopic Turbinoplasty Vs Conventional Inferior Turbinectomy}

\section{CONCLUSION}

Endoscopic turbinoplasty is more effective than conventional surgical technique for inferior turbinate hypertrophy as it leads to less post-operative pain, reduced nasal crusting and earlier healing

\section{Conflict of Interest: None.}

\section{Authors' Contribution}

AR \& MR: Data collection, conceptualization and statistical analysis, SFK: Data collection and conceptualization, MA: Statistical analysis, KA: Proof reading, MZ: Writing

\section{REFERENCES}

1. Farmer SE, Eccles R. Chronic inferior turbinate enlargement and the implications for surgical intervention. Rhinol 2006; 44(2): 234238.

2. Marieb EN. Essential of Human Anatomy and Physiology. (7th edition). Benjamin Cummings, San Francisco. 2003, Available at: https://www.biblio.com/9780805353853

3. Salzano FA, Mora R, Dellepiane M, Zannis I, Salzano G. Radiofrequency, high-frequency, and electrocautery treatments vs partial inferior turbinotomy: microscopic and macroscopic effects on nasal mucosa. Arch Otolaryngol Head Neck Surg 2009; 135(1): 752-758.

4. Hammad MS, Gomaa MA. Role of some anatomical nasal abnormalities in rhinogenic headache. Egypt J Ear Nose Throat Allied Sci 2012; 13(2): 31-35.

5. Kumar SK, Aradhya A.S. Total inferior turbinectomy versus inferior turbinoplasty-A compartitive study. J Evolut Med Dent Sci 2019; 7(35): 3830.

6. El-Magd EAA, Rezk I, Sobh KM. A comparative study between sub mucous diathermy with or without inferior partial turbinectomy. Inter J Otolaryngol Head-neck Surg 2018; 7(2): 26-33.

7. McCoul ED, Todd CA. Posterior inferior turbinate hypertrophy (PITH). Otolaryngol-Head Neck Surg 2019; 160(2): 343-346.

8. Omranifard M, Adib M, Boroujeni SE, Tirani FD, Asadi S. Comparative study of the effectiveness of sub mucosal partial inferior turbinectomy and out fracture of inferior turbinate in the nasal respiratory function of rhinoplasty patients. Aesth Plast Surg 2019; 1(1): 1-5.

9. Yamasaki A, Levesque PA, Bleier BS, Busaba NY, Gray ST, Holbrook $\mathrm{EH}$, et al. Improvement in nasal obstruction and quality of life after septorhinoplasty and turbinate surgery. Laryng 2019; 2(1): 27-30.

10. Harju T, Honkanen M, Vippola M, Kivekäs I, Rautiainen M. The effect of inferior turbinate surgery on ciliated epithelium: A randomized, blinded study. Laryng 2019; 129(1): 18-24.
11. Yan $\mathrm{CH}$, Hwang PH. Surgical management of nonallergic rhinitis. Otolaryngol Clin North Am 2018; 51(5): 945-955.

12. Kompelli AR, Janz TA, Rowan NR, Nguyen SA, Soler ZM. Cryotherapy for the treatment of chronic rhinitis: a qualitative systematic review. Am J Rhinol Allerg 2018; 32(6): 491-501.

13. Komshian SR, Cohen MB, Brook C, Levi JR. Inferior turbinate hypertrophy: a review of the evolution of management in children. Am J Rhinol Allerg 2019; 33(2): 212-219.

14. Acevedo JL, Camacho M, Brietzke SE. Radiofrequency ablation turbinoplasty versus microdebrider-assisted turbinoplasty: a systematic review and meta-analysis. Otolaryngol-Head Neck Surg 2015; 153(6): 951-956.

15. Lund VJ, Kennedy DW. Quantification for staging sinusitis. the staging and therapy group. Ann Otol Rhinol Laryngol Suppl 1995; 167(1): 17-21.

16. Gindros G, Kantas I, Balatsouras DG, Kandiloros D, Manthos AK. Mucosal changes in chronic hypertrophic rhinitis after surgical turbinate reduction. Eur Arch Otorhinolaryngol 2009; 266(2): 1409-1416.

17. Imad H, Javed, Sanaullah. Comparison of submucosal diathermy with partial inferior turbinectomy: a fifty case study. J Postgrad Med Inst 2012; 26(2): 91-95.

18. Luczaj J, Rogowski M. Submucosal bipolar radiofrequency therapy for treatment of turbinate hypertrophy. Otolaryngologiapolska= Polish Otolaryngol 2007; 61(3): 290-294.

19. Fradis M, Malatskey S, Magamsa I, Golz A. Effect of submucosal diathermy in chronic nasal obstruction due to turbinate enlargement. Am J Otolaryngol 2002; 23(1): 332-336.

20. Warwick-Brown NP, Marks NJ. Turbinate surgery: how effective is it?. Orl 1987; 49(6): 314-320.

21. Aboulwafa WH, Saad AE, Abbas AY, Elewa MA, Eldahshan TA Comparative study between submucosal diathermy and endoscopic partial turbinectomy in hypertrophied inferior turbinate. Egyptian J Hospital Med 2019; 74(4): 809-819.

22. Kumar MP, Karthikeyan P, Coumare VN. Comparison of endoscopic turbinoplasty versus conventional partial inferior turbinectomy in chronic hypertrophic rhinitis. Ind J otolaryngol Head Neck Surg 2018; 18(1): 1285-1288.

23. Ali BH, Awad OG, Ibrahim A, Azez AA. Assessment of safety and efficacy of extraturbinal microdebrider-assisted turbinoplasty versus partial inferior turbinectomy. Egypt J Otolaryngol 2019; 35(1): 17-20.

24. Rakover Y, Rosen G. A comparison of partial inferior turbinectomy and cryosurgery for hypertrophic inferior turbinates. J Laryngol Otol 1996; 110(8): 732-735.

25. Serrano E, Percodani J, Yardeni E, Lombard L, Laffitte F, Pessey JJ. the holmium: YAG laser for treatment of inferior turbinate hypertrophy. Rhinol 1998; 36(2): 77-80. 